\title{
I-10 道路工事完成図書を用いた空間データ基盤の更新に関する研究
}

Updating Spatial Data Infrastructure Using Road Construction Completion Reports

\author{
三上 市藏 1 \\ 窪田 諭 2 \\ 中村 修策 3 \\ 田中 孝幸 4 \\ Ichizou MIKAMI \\ Satoshi KUBOTA \\ Shusaku NAKAMURA \\ Takayuki TANAKA
}

【抄録】 “国土地理院では，電子国土の基盤である空間データ基盤を整備している。しかし，現在の更 新頻度では工事などにより変化する地物形状を取得できず, 最新の情報を必要とする行政業務において 空間データ基盤を利用できない. 重要な社会基盤である道路では, 工事完了後に工事完成図書が納品さ れる．このデータを活用すれば，空間データ基盤の道路地物を更新できると考えられる.

本研究では, 空間データ基盤の道路地物の更新の仕組みを提示した。 まず，道路工事完成図書の測量 成果を空間データ基盤の更新に利用できるように標準化した。そして，標準化した道路工事完成図書を 用いた空間データ基盤の更新の手法を作成した。

【Abstract】 The Spatial Data Infrastructure is constructed by Geographical Survey Institute. However, the data can't be used for the administrative works under the present update frequency, because the transfiguration of feature as the result of the constructions isn't represented. The construction completion report is submitted after completion of road construction. The report can support the update of the Spatial Data Infrastructure. In this study, a method for updating the Spatial Data Infrastructure by using the report was presented.

【キーワード】 空間データ基盤, データ更新, 道路, 電子国土, GIS

【Keywords】 Spatial Data Infrastructure, Update, Road, Digital Earth, GIS

\section{1. まえがき}

国土に関する情報 GIS を用いて電子的に統合 し，現在・過去の三次元仮想時空間内のデジタル 情報として再現するとともに，国民がインター ネットを通じて自由にその情報を利用できる環境 の構築を目指した「電子国土」1)が構想され，そ の実現に向けた施策 2)が進められている. その一 つとして, 電子国土の基盤となる空間データ基盤 の整備が進められている. 空間データ基盤は, 国 土の骨格を成す道路・河川・行政界などの主要な 社会基盤の空間データによって構成される。この 空間データ基盤を行政業務において共用すること
により，各行政業務における測量の重複を省くこ とができ，測量コストを削減できる。

空間データ基盤を整備するために, GIS 関係省 庁連絡会議では，国土空間データ基盤標準および 整備計画 3)を策定し，その実施計画である GIS ア クションプログラム 2002-20054)の中で，国土地 理院が空間データ基盤として数值地図 2500 およ び数值地図 25000 を整備すると定められている. 数值地図 2500 は，都市計画区域に対する縮 尺 $1 / 2,500$ 地形図と同等の空間解像度をもつデジ タル地形データである.また, 数值地図 25000 は, 全国を網羅した縮尺 1/25,000 地形図と同等の空

1 フェロー 工博 関西大学工学部都市環境工学科 教授 (E-mail:gfh00126@nifty.com)

2 正会員 工修 （株）オージス総研 コンサルティング部

3 正会員 工修 パシフィックコンサルタンツ（株）

4 学生会員 関西大学大学院土木工学専攻博士課程前期課程

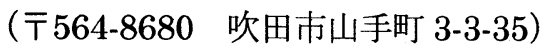

（广550-0023 西区千代崎 3 南 2-37）

（テ 206-8550 多摩市関戸 1-7-5）

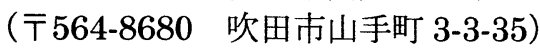


間解像度をもつデジタル地形データである．空間 データ基盤の更新頻度については, 数值地図 2500 は定期的更新, 数值地図 25000 は年次更新と定め られている。

ここで，最も重要な社会基盤である道路に着目 すると, 上記の空間データ基盤の更新頻度では, 工事により変化する地物形状をリアルタイムに取 得できない，そのため，最新の情報を必要とする 行政業務において空間データ基盤を利用できず, 各行政主体は基盤データを道路 GIS5)や統合型 GIS6)のように空間データ基盤とは別の応用ス キーマ形式で整備している。これは空間データ基 盤の整備・更新とその他の行政業 務で測量が重複しており，空間 データ基盤が電子国土の基盤とし ての役割を充分に果たしていない ことを示している. そのため，空 間データ基盤の道路地物が常に最 新の情報を保持できるようにする 必要がある。

そこで, 本研究では, 空間デー 夕基盤を電子国土の基盤として利 用できるようにするために，空間 データ基盤の効率的な更新の仕組 みを提示する。

\section{2. 道路地物の更新手法の構想}

現実国土の道路地物は道路工事 によって形状が変更される．道路 工事では，工事完了時に工事完成 図書が納品 7)される.この図書に 含まれるデータを活用すれば，空 間データ基盤をリアルタイムに更 新できると考えられる. 図-1に現 状の道路工事完成図書に関する業 務を UML を用いて分析したもの を示す．現状の業務では，道路工 事完成図書は納品後に再利用され ておらず，空間データ基盤の更新 だけでなく道路台帳の整備のため にも新たに測量が行われている。 そこで，本研究では，道路工事完
成図書を再利用することによって空間データ基盤 を更新する仕組みを提案する。

しかし，現状の道路工事完成図書は，支払い工 事費を算出するための資料であり，測量成果に関 する規定がないため，道路工事によって変化した 道路形状を必ずしも正確に表しておらず，そのま までは空間データ基盤の更新に利用できないとい う問題がある。

そのため，道路工事完成図書が空間データ基盤 の更新に利用できる品質を満足するように，その 測量成果を規定する．測量に関連する規定を考え るにあたっては，仕様規定と性能規定の二つのア

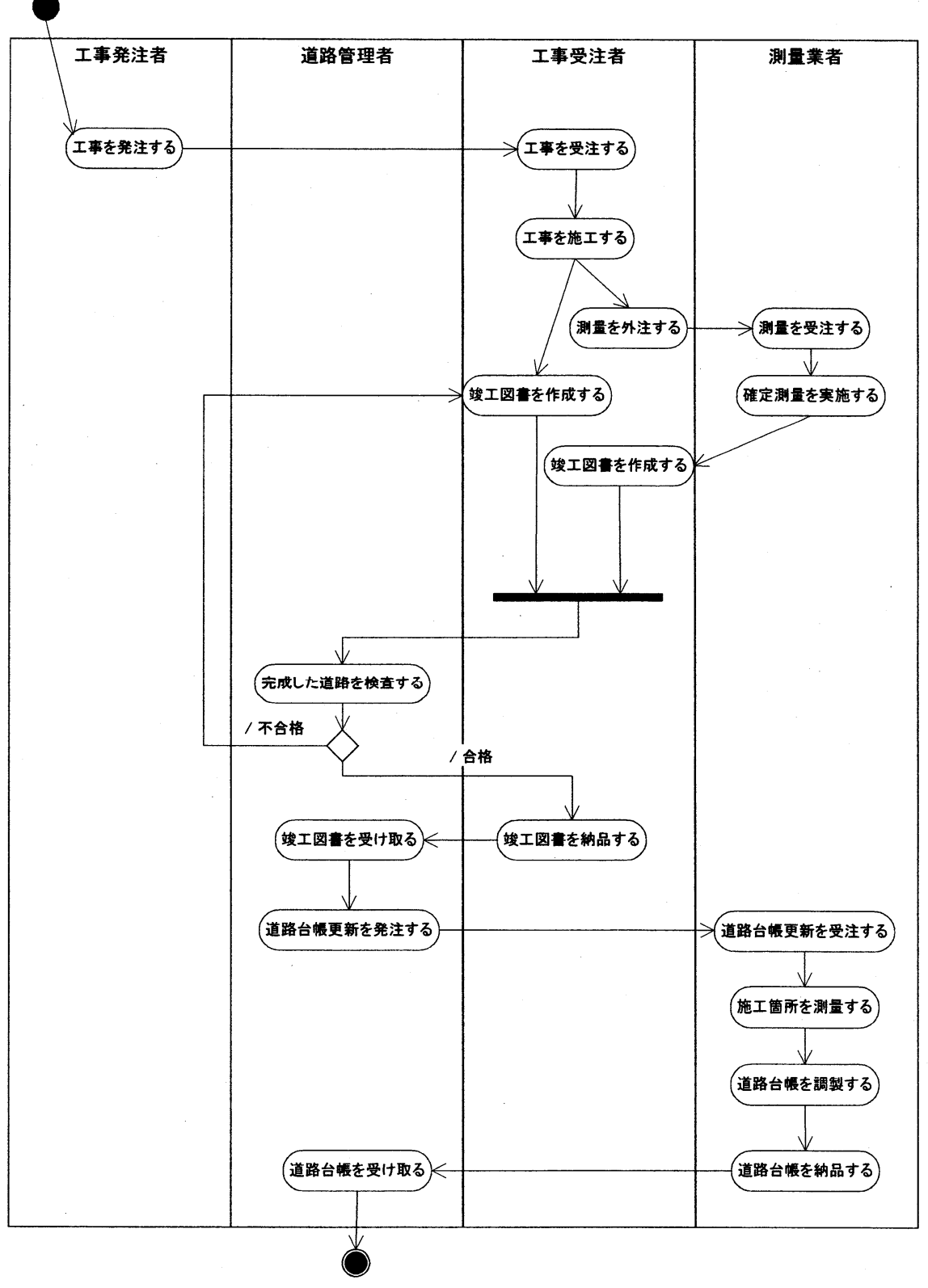

図-1 現状の道路工事完成図書に関する業務フロー 
プローチがある．仕様規定は従来から行われてい る測量規定で, 作業方法・測量機器・取得する地 物などが詳細に規定されているが，先端測量技術 の活用が困難であるという久点を持つ.一方, 性 能規定によれば, 発注者が要求する品質の成果品 を提出できれば，受注者が作業方法を決定できる ので，先端測量技術の活用により測量コストを縮 減することが可能である。したがって, 不要な測 量コストの縮減のために, 本研究では測量に関す る規定に性能規定を採用する. そして, 上記の規 定に則って作成された道路工事完成図書を用いた 空間データ基盤の道路地物の更新手法を提案する. 更新手法については，行政間での測量の重複を生 じさせないために, 空間データ基盤の管理者の再 定義を行い, 本研究の規定に則って作成される道 路工事完成図書を用いた空間データ基盤の更新フ ローを作成する。

\section{3. 道路工事完成図書における測量成果の規定}

\section{1 道路工事完成データの定義}

本章では，道路工事完成図書を空間データ基盤 の更新に利用できるように, 道路工事完成データ として規定する．道路工事完成デー夕は，従来の 道路工事完成図書 7)に本研究において定義する測 量成果を追加したものである．測量成果は，空間 データ基盤の更新および道路台帳の整備に再利用 されるため, 空間データ基盤の整備に必要な地物 および道路管理者が現況平面図として管理すべき 地物の絶対座標を持つこととする.

前章の構想に基づく性能規定を実現するために, 国際標準規格 ISO/DIS19106 (Profile : プロファ イル）に準拠した地理情報標準 8)の「製品仕様書」 を採用して測量成果を規定する．製品仕様書は， 空間データを作成あるいは交換する際，その基準 となる論議領域を定義する上で，製品仕様書に記 載されるべき必要最低限の項目を規定したもので ある. 本研究では, この項目に沿って, 空間デー 夕基盤の更新に必要な測量成果を明らかにする.

工事発注者は, 本研究の規定に従って製品仕様 書を作成すれば，成果品である道路工事完成デー タの品質を空間データ基盤の更新に必要なものと
して保証できる.

\section{2 取得する地物}

取得する地物は, 道路法 9)および道路構造令 10) によって道路管理者に管理が義務付けられている 道路地物とする，道路法では，道路の維持管理に 必要な道路台帳付図には縮尺 $1 / 1,000$ が要求され るため, 道路地物は, 国土交通省が定めている公 共測量作業規程 11)(以下，公共測量作業規程)の縮 尺 $1 / 1,000$ のディジタルマッピング(DM)取得分類 基準を参照して, 点・線・面で表現するものとす る.

\section{（1）点として取得する地物}

公共測量作業規程において地図情報レべ ル 1000 における「点」として示されている地物 である並木，街灯，交通標識，道路元標を「点」 として取得する.

\section{（2）線として取得する地物}

公共測量作業規程において地図情報レベ ル 1000 における「線」として示されている地物 である道路境界線，駒止め，ガードレール，共同 溝を「線」として取得する。

\section{(3) 面として取得する地物}

地理情報標準では地物形状を「面」として表現 する概念が存在するが，公共測量作業規程のディ ジタルマッピング取得分類基準では「面」として 表現する概念は存在しない. 地物の外周を線とし て取得する場合を考えると，「面」として取得して も取得項目は変化せず地物領域を表現することが 可能となり, 領域内と領域外の判別を省くことが できる，そのため，外周を取得する項目に関して は，位置形状を「面」として取得する。

本研究では, 道路情報提供施設, 車両監視装置, 気象観測装置, 緊急連絡装置, 材料置き場, 中央 帯, 交通島, 側溝, 路肩, 停車帯, 植樹帯, 駐車 場，トンネル，道路橋を面として取得する。

\section{3 応用スキーマ}

製品仕様書には，応用スキーマによって地物と その関連を表現することが定められている，応用 スキーマは, 空間スキーマ・時間スキーマ・地理 識別子による空間参照およびメタデータにおける 
データ品質要素情報を参照し，UML を用いて データの集合毎の空間データの構造を記述する.

本節では, 地理情報標準 9)の応用スキーマのた めの規則に従って道路工事完成データの応用ス キーマを作成する，幾何形状表現は，前節で定め た地物に対して, 点は GM_Point, 線は GM_Curve，面はGM_Surface で表す.作成した 応用スキーマの一部を図ー2 に示す．最上位のク ラスである道路地物 (Road) が道路本体 (MainBody) ・道路橋(HigwayBridge) ・トンネル (Tunnel)・道路付属物(Attachment)の各クラスを 持ち, さらに道路本体は車道(CarriageWay) - 歩 行者専用道路(PedestrianPath) - 自転車専用道路 (BicyclePath) - 歩行者自転車専用道路 (PedestrianAndBicyclePath)の各クラスを持っ ていることを示している。これらの地物はそれぞ
れが幾何形状を表す属性データと管理のための時 間を表す属性データ(TM_Instance)を有しており， 幾何形状に関しては，地物を構成する最小の単位 である測点(PointOfSurvey)から構成されている. 時間に関しては，地物それぞれが供用開始時間 (StartTime) と供用終了時間(EndTime)を有して いる.

\section{4 符号化仕様}

道路工事の受発注者および空間データ基盤の利 用者が応用スキーマに準拠した空間データを交 換・共用するためには、空間データの標準化が必 須である. 本研究では, 国際標準規格としてデー 夕の永続性が保証されている XML（Extensible Markup Language）で記述されたデータを採用 する。そして，地理情報標準の応用スキーマを

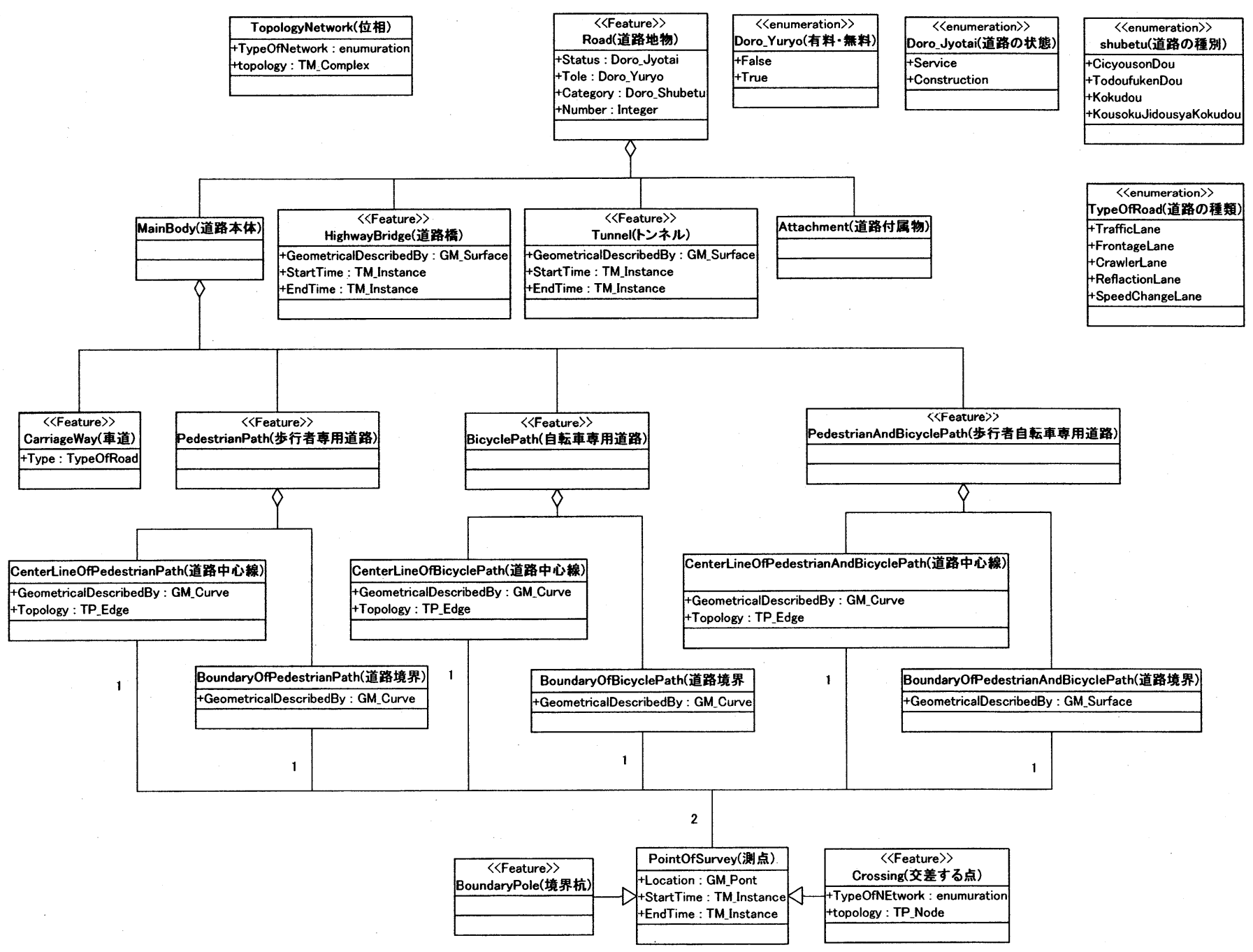

図-2 道路工事完成データの応用スキーマ(一部) 
XML に変換するための規則「符号化の規則」に 基づき、第 3.3 節で作成した応用スキーマを XML で符号化する. 図-3に本研究で作成した XML ス キーマの一部を示す.

\section{5 品質要求}

地理情報標準では，製品仕様書に従って作成さ れた空間データが製品仕様書に適合している度合 を定義するために, 品質原理の中で品質情報の報 告内容を規定している，そこでは，空間データの 品質要素を完全性, 論理一貫性, 位置正確度, 時 間正確度，主題正確度に分類している.さらに， 各品質要素は, 品質の内容によりデータ品質副要 素に細分化されている.以下に, 道路工事完成デー 夕の品質要求を地理情報標準 8)の規定に従い定義 する.

\section{（1）完全性}

地物，属性，地物間関係の存否について定義す る.

\section{(a) 過剩}

作成された道路工事完成データの中の過利デー 夕の割合を決める. 道路工事完成データは, 空間 データ基盤の更新に利用されるため, 道路地物を 正確に反映している必要があり, 地物の過剩は許 されない. そのため, 過剒の誤率を $0 \%$ と定める.

\section{(b) 漏れ}

作成された道路工事完成データからの欠落デー タの割合を決める. 過剩と同様に, 漏れの誤率を $0 \%$ と定める。

\section{（2）論理一貫性}

データの構造，属性および関係に関する論理的 規則の忠実度を定義する。

\section{(a) 概念一貫性}

作成された道路工事完成データが応用スキーマ に従っている割合を定める．道路工事完成データ は空間データ基盤の更新に利用されるため, 道路 工事完成データは応用スキーマに則している必要 がある。

XML が XMLSchemaに準拠しているかどうか 検証する XML パーサを用いれば，応用スキーマ

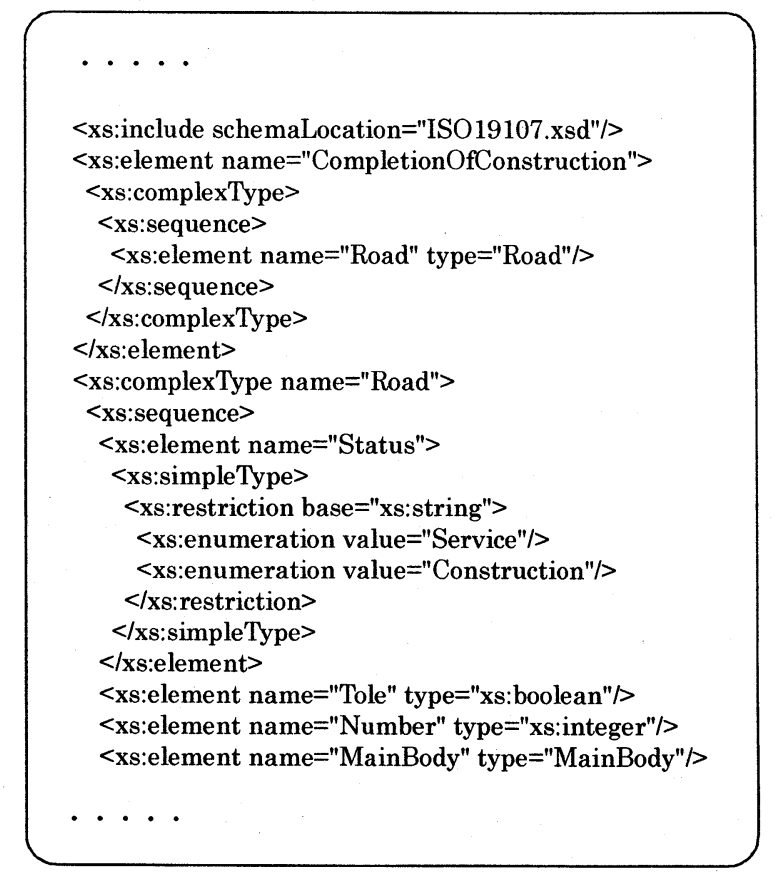

図-3 道路工事完成データの XMLSchema(一部)

への忠実度の確認および修正が容易にできるため, 概念一貫性の誤率を $0 \%$ と定める.

(b) 定義域一貫性

定義域に対する值の正確さを表す．概念一貫性 と同様に，定義域一貫性の誤率を $0 \%$ と定める.

(c) フォーマットー貫性

道路工事完成データの構造の構造規則への忠実 さを表す．概念一貫性と同様に，フォーマット一 貫性の誤率を $0 \%$ と定める.

(d) 位相一貫性

成果品のデータセットの位相特性の正確さを表 す. 道路工事完成データは空間データ基盤の更新 に利用され，空間データ基盤内の地物の位相と接 合されるため，位相の誤差汸許されない。そのた め，位相一貫性の誤率を 0\%と定める。

\section{(3) 位置正確度}

地物の位置の正確度を定める. 本研究では,道路 工事完成データとして提出される測量成果を対象 とするため，グリットデータ外部正確度および内 部正確度は定めない，外部正確度については，報 告された座標值が真と見なされる值に近接する度 合いを表す，行政情報として道路工事完成データ を再利用する場合，それには，道路法で定められ ている道路台帳付図と同等の縮尺 $1 / 1000$ 以上の 
精度が求められる. 本研究では, 公共測量作業規 程 12)に従って, 平均值 $\pm 70 \mathrm{~cm}$ 以内の誤差が $68.27 \%$ 以内, 平均值 $\pm 140 \mathrm{~cm}$ 以内の誤差が 95.45\%以内であることと定義する.

\section{(4) 時間正確度}

地物の時間属性と時間関係の正確度を定める。 時間測定正確度は, 項目の時間参照の正確性を表 す. 道路工事完成データは, 空間データ基盤の更 新に利用されるため, 更新の際の指標となる時間 には誤差は許されない. そのため, 時間測定正確 度の誤率を $0 \%$ と定める.

\section{(5) 主題正確度}

非定量的属性の正確性, 地物の分類と地物間関 係の正確性を定める. 分類の正確性は, 地物また は属性に割り当てられたクラスの論議領域との比 較を表す. 道路工事完成データは, 空間データ基 盤の更新に利用されるため, 地物の分類に誤りが あってはならない. そのため, 主題正確度の各項 目に関して誤差を $0 \%$ と定める.

\section{6 参照系}

道路工事完成データは世界測地系に基づく平面 直角座標系で作成されるものとする，世界測地系 では, IG(International Association of Geodesy) と IUGG(International Union of Geodesy and Geophysics)によって採択された擬似地球 モデルである楕円体(GRS80)を採用しており， IERS が構築している三次元直交座標系である ITRF 座標系を採用している. 本研究では, これ らの楕円体および座標系を採用する. また, 垂直 の基準点を東京湾平均海面として、垂直の原点を 日本水準原点とする. 経緯度に関しては, 赤道お よび本初子午線グリニッジ経度を基準とする.

\section{4. 空間データ基盤の更新手法の提案}

本章では, 前章での規定に則って作成された道 路工事完成データを用いた空間データ基盤の更新 手法を提案する. まず, 空間データ基盤の管理者 を定義する. 次に, 道路工事完成データを用いた 空間データ基盤の更新フローを提案する.

\section{1 空間データ基盤の管理者の定義}

電子国土は位置情報を介して多くの行政情報と 民間の情報の統合を図るものであるため, 基盤と なる空間データ基盤は, 道路 GIS や統合型 GIS などの行政主体が整備している GIS と整合を図 り，それらを統合するものであるべきである。

現在, 測量法によって策定が義務付けられてい る長期計画によって国土地理院による空間データ 基盤の管理が義務付けられている. 本研究でも同 様に, 基準点や地形データなど根幹となるデータ を管理する国土地理院が空間データ基盤を管理・ 運用するものとする. ただし, 現在の国土地理院 が独自に空間データ基盤を常に最新の状態に更新 することは, 対象地物数と財政状況を鑑みると不 可能であると考えられる，そこで，国土地理院は 自ら空間データ基盤の各地物のデータを取得して 更新するのではなく, 空間データ基盤の各地物を 現実国土において管理する行政主体に常に最新の 地物のデータを国土地理院に提出するよう義務付 け，提出されたデータを用いて空間データ基盤を 更新することとする.

その際，国土地理院は更新による空間データ基 盤の各地物間の整合性にのみ責任を持ち, 現実に おける法律上の地物の管理者が, 保有を義務付け られている地物の品質に責任を持つこととする.

\section{2 空間データ基盤の更新フロー}

道路工事完成データを用いた空間データ基盤の 更新フローとして図-4 を提案する.工事発注者は 道路工事を発注する際に, 成果品である道路工事 完成データの品質要求を規定する製品仕様書を作 成する.工事受注者は工事箇所の確定測量を行い, 製品仕様書に従って工事による地形の変更を反映 した道路工事完成データを作成する. 工事発注者 は道路工事完成データの受領時に工事受注者が定 められた適切な品質評価を実施したかを検査する. 検査後, 工事発注者は検查済みの道路工事完成 データを道路管理者に移管するとともに国土地理 院に提出する. 国土地理院は提出された道路工事 完成データを用いて空間データ基盤を更新する.

本研究のフローでは, 道路工事完成図書は道路 


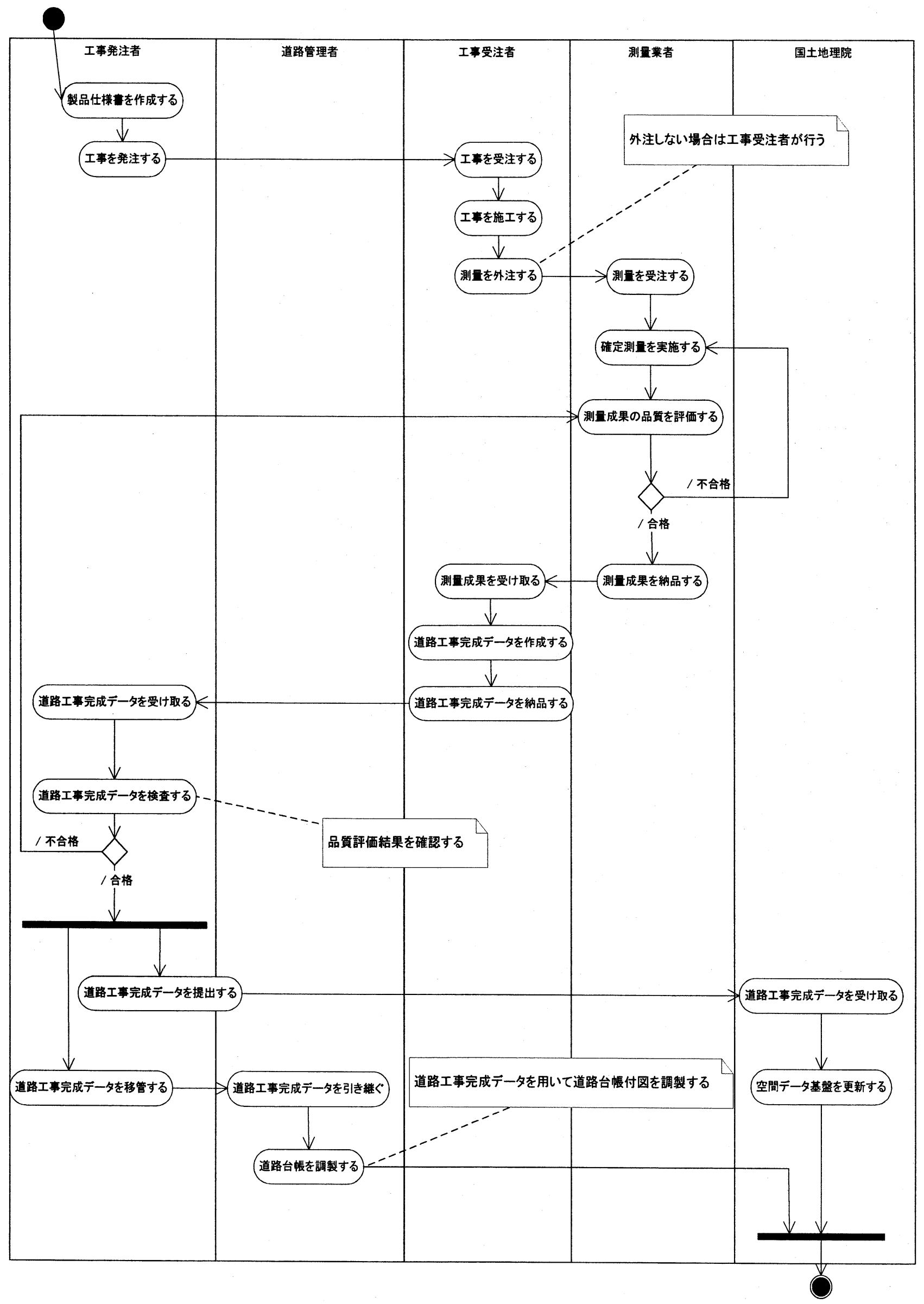

図-4 空間データ基盤の更新フロー 
工事完成データとして空間データ基盤の更新およ び道路台帳の整備に再利用される. そのため, 空 間データ基盤の更新のための測量と道路台帳の更 新のための測量を省くことができ効率的である. また，工事発注者に国土地理院への道路工事完成 データの提出を義務付けることにより, 現実国土 における道路の形状の変化が常に空間データ基盤 へと反映される.

\section{5. あとがき}

道路を対象とすると, 現状の空間データ基盤の 更新頻度では，工事などにより変化する道路地物 の形状を空間データ基盤にリアルタイムに反映で きないので, 最新の情報を必要とする様々な行政 業務で空間データ基盤が利用できない.そのため, 空間データ基盤の道路地物が常に最新の状態に更 新されている必要がある.

本研究では, 道路工事によって変化した地物形 状をリアルタイムに空間データ基盤へと反映させ る手法を提案した．まず，空間データ基盤の更新 に利用できる品質を満足するように，道路工事完 成図書の測量成果の品質要求を規定し，製品仕様 書の規定を作成した. 次に, 上記で規定した製品 仕様書に従って作成された道路工事完成データを 用いた空間データ基盤の更新のフローを提案した。

今後は，今回作成した更新フローを用いて実際 に空間データ基盤の更新を行い, 更新手法の妥当 性を検証するとともに, 道路地物だけでなく行政 で扱う地物全体を視野に入れ，道路 GIS や統合型 GIS と空間データ基盤を整合させ, 広く行政業務 全体の効率化と高度化を図る.

\section{参考文献}

1)村上真幸: 電子国土構想とは, JACIC 情報, 日本建設情報総合センター, Vol.16, No.3, pp.22-26, 2001.10.

2)国土地理院政策愁談会:21世紀の基本測量 〜 電子国土の実現に向けて〜, 国土地理院政策懇 談会報告書, 2000.12 .

3)GIS 関倸省庁連絡会議: 国土空間データ基盤の 整備および GIS の普及促進に向けての長期計 画, 1996.12 .

4)GIS 関係省庁連絡会議: GIS アクションプログ ラム 2002-2005, 2002.2.

5)柳澤茂樹, 鈴木弘之, 弘嶋浩二, 岩切昭義 : 道 路 GIS の検討, 第 4 回 建設情報研究会研究発 表会資料集，日本建設情報総合センター， pp.21-34, 2002.11.

6) 総務省自治行政局地域情報政策室: 統合型の 地理情報システムに関する全体指針, 2001.7.

7)国土交通省 : 工事完成図書の電子納品要領案, 2001.8.

8)地理情報標準推進委員会 : 地理情報標準 第 2 版, 国土地理院, 2002.9.

9)道路法令研究会 : 道路法解説 改訂 3 版, 大成 出版社, 2002.9 .

10) 日本道路協会交通工学委員会道路構造規格 小委員会 : 道路構造令の解説と運用, 日本道路 協会, 1983.2 .

11)国土交通省大臣官房技術調查課：国土交通省 公共測量作業規程, 日本測量協会, 2002.4. 